\title{
Correction to: Enzyme-Free Glucose Sensor Based on Star-Like Copper Particles-Polyaniline Composite Film
}

\author{
Ouafia Belgherbi ${ }^{1,2} \cdot$ Dalila Chouder $^{2}$. Delloula Lakhdari ${ }^{1}$. Charif Dehchar ${ }^{1} \cdot$ Samiha Laidoudi $^{1}$ - Leila Lamiri ${ }^{1}$. \\ Abderrazak Hamam ${ }^{1} \cdot$ Lamria Seid $^{2,3}$
}

Published online: 27 May 2020

(c) Springer Science+Business Media, LLC, part of Springer Nature 2020

\section{Correction to: \\ Journal of Inorganic and Organometallic Polymers and Materials \\ https://doi.org/10.1007/s10904-020-01554-1}

The article "Enzyme-Free Glucose Sensor Based on StarLike Copper Particles-Polyaniline Composite Film", written by Ouafia Belgherbi, Dalila Chouder, Delloula Lakhdari, Charif Dehchar, Samiha Laidoudi, Leila Lamiri, Abderrazak Hamam and Lamria Seid, was originally published electronically on the publisher's internet portal (currently
SpringerLink) on 29 April 2020 with open access. With the author(s)' decision to step back from Open Choice, the copyright of the article changed on 29 May 2020 to () Springer Science+Business Media, LLC, part of Springer Nature 2020 and the article is forthwith distributed under the terms of copyright.

Publisher's Note Springer Nature remains neutral with regard to jurisdictional claims in published maps and institutional affiliations.
The original article can be found online at https://doi.org/10.1007/ s10904-020-01554-1.

\section{Ouafia Belgherbi}

o.belgherbi@crti.dz

1 Research Center in Industrial Technologies CRTI, P.O. Box 64, 16014 Cheraga, Algiers, Algeria

2 Laboratoire D'Energétique Et D’Electrochimie du Solide (LEES), Département de Génie Des Procédés, Faculté de Technologie, Université Sétif-1, Sétif, Algeria

3 Département D’Agronomie, Université Mohamed El Bachir El-Ibrahimi, Faculté des Sciences de la Nature et de la Vie et sciences, 34000 Bordj Bou Arréridj, Algeria 